\title{
Species-specific variation in sulfide physiology between closely related Vesicomyid clams
}

\author{
Shana K. Goffredi* , James P. Barry \\ Monterey Bay Aquarium Research Institute (MBARI), 7700 Sandholdt Road, Moss Landing, California 95039, USA
}

\begin{abstract}
Symbioses involving sulfide-oxidizing bacteria and metazoan phyla dominate invertebrate assemblages at cold seeps and hydrothermal vents worldwide. The predominant species inhabiting cold seeps in Monterey Bay are the vesicomyid clams Calyptogena kilmeri and C. pacifica. The growth and survival of these clams depend directly upon the productivity of their chemoautotrophic endosymbionts, which is fueled by the oxidation of sulfide. For this reason, sulfide availability and sulfide-related physiology are thought to be the most influential factors governing the productivity of these associations. Both species inhabit sulfide-rich sediments and depend nutritionally on their symbionts, yet many aspects of their life histories differ considerably. Our results indicate that C. pacifica, which inhabits areas with lower environmental sulfide levels, is physiologically poised for the uptake and transport of sulfide, indicated by increased sulfide consumption rates, sulfide-binding ability, and internal sulfide levels. C. pacifica also has a greater potential for symbiont energy turnover, supported by increased sulfide oxidation potential, enzymes involved in sulfur metabolism, and bacterial densities. Conversely, C. kilmeri demonstrates a less effective sulfide uptake mechanism and, therefore, a specific need for higher environmental sulfide levels. It appears that the abilities of these 2 species to process sulfide differ greatly and reflect not only the environments in which they are found but also the capabilities of their symbionts. This research represents the first comparative investigation of the physiological functioning of closely related species in chemosynthetic symbioses and elucidates the constraints and advantages posed by different modes of sulfide (energy) uptake and assimilation in these, and perhaps other, symbiotic organisms.
\end{abstract}

KEY WORDS: Vesicomyid · Chemoautotrophic · Symbiont · Monterey · Physiology · Sulfide • Calyptogena

\section{INTRODUCTION}

In the late $1970 \mathrm{~s}$, scientists discovered novel deepsea ecosystems fueled primarily by chemosynthetic oxidation of hydrogen sulfide (Corliss et al. 1979). In Monterey Bay, California, sulfide-rich systems, teeming with chemosynthetically supported life were first discovered in the 1980s near $3200 \mathrm{~m}$ depth (Embley et al. 1990). Since then, scientists have focused on a number of cold seep areas in Monterey Bay where dense invertebrate communities have been found (Barry et al. 1996). The vesicomyid clams Calyptogena kilmeri and C. pacifica are the 2 predominant species

*E-mail: goffredi@mbari.org within Monterey seeps shallower than 2200 m depth. Like all vesicomyids, these clams have reduced digestive systems and exist in symbiotic relationships with carbon-fixing, sulfide-oxidizing endosymbiotic bacteria, upon which they rely for organic nutrients (Felbeck 1981, Cavanaugh 1983, Fiala-Médioni \& Métivier 1986). Host-symbiont relationships among vesicomyids are thought to be stable, obligate (at least for the host), and species specific, in that a single dominant symbiont type is unique to each host species (Distel 1998). The host presumably benefits from nutritional integration with the symbiont, which overcomes the problem of low food availability in the deep sea, whereas the symbiont benefits from an environment protected from fluctuations of necessary metabolites. 
Despite seemingly similar modes of existence, Calyptogena kilmeri and C. pacifica appear to use different ecological and physiological strategies to thrive in the seep environment. For instance, the densities of $C$. kilmeri and C. pacifica are known to vary depending upon the chemical conditions of the sediment pore water in which they are found (Barry et al. 1996, 1997). Seeps in Monterey Bay exhibit a broader range of environmental sulfide variability than most chemo-

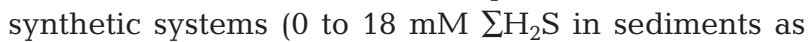
shallow as $4 \mathrm{~cm}$ ), and thus, provide an opportunity for comparison of species inhabiting extreme chemical gradients. C. kilmeri dominates in areas with the highest sulfide exposure reported to date (4 to $18 \mathrm{mM}$ ), whereas $C$. pacifica dominates in areas of lower sulfide (0 to $4 \mathrm{mM}$; Barry et al. 1996, 1997, S.K.G. unpubl. data). This difference in habitat sulfide suggests potential differences in the sulfide physiology of these 2 species, including sulfide uptake, binding, transport, tolerance, and bacterial conversion of sulfide into energy.

In order for chemosynthetic symbioses to thrive, symbionts must have access to an electron donor, used as an energy source (sulfide), and an electron acceptor (oxygen or nitrate). Vesicomyid clams accomplish the uptake of both sulfide and oxygen, which do not normally exist in the same water mass due to rapid oxidation, by bridging spatially the gap between sulfide-rich sediment and oxygen-laden seawater. These species of clam orient themselves with the anterior (foot) positioned within sulfide-rich sediment, and the siphons extended into overlying oxygenated water. Their depth of burial within the sediment is somewhat variable and may be linked to the depth and steepness of the interstitial sulfide gradient. Sulfide is acquired from the reduced sediment through their highly vascularized foot, using a unique extracellular sulfide-binding component (Childress et al. 1993). Although the exact nature of this component is unknown, researchers have suggested that zinc may play an important role in sulfide binding by this compound (Childress et al. 1993).

Chemo(thio)autotrophic associations depend upon the productivity of their symbiotic bacteria, which require sufficient sulfide availability. For this reason, both the supply of sulfide and sulfide-related physiological processes may limit production by the symbionts or host or both . Sulfide-related physiology generally encompasses 2 important physiological functions: (1) uptake and transport of sulfide; and (2) bacterial conversion of sulfide into energy (Fig. 1).

Invertebrate hosts of chemoautotrophic symbionts have demonstrated substantial sulfide uptake from the environment, which results in extremely elevated concentrations of bound internal sulfide, despite the fact that sulfide is poisonous to most metazoans (Childress

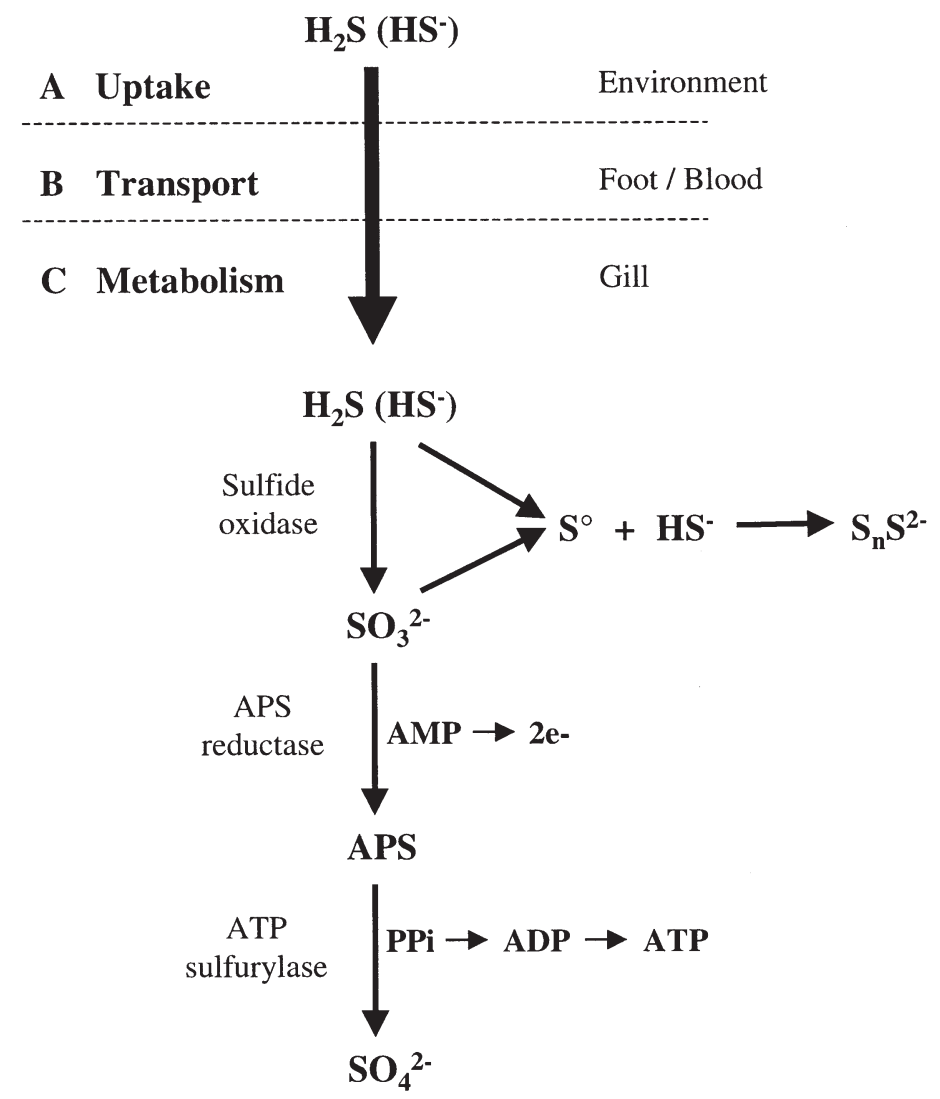

Fig. 1. Diagram of various biochemical and physiological factors thought to be involved in sulfide acquisition and conversion to energy by chemo(thio)autotrophic symbioses. $\mathrm{S}^{\circ}$, elemental sulfur; $\mathrm{S}_{\mathrm{n}} \mathrm{S}^{2-}$, polysulfides, $\mathrm{SO}_{3}{ }^{2-}$, sulfite; $\mathrm{AMP}$, adenosine monophosphate; APS, adenosine phosphosulfate; $\mathrm{PPi}$, inorganic phosphate; $\mathrm{SO}_{4}{ }^{2-}$, sulfate

et al. 1991, Goffredi et al. 1997). To achieve sulfide uptake rates and internal sulfide levels sufficient to support bacterial production of organic carbon, the host must possess extremely effective sulfide-concentrating mechanisms. Previous studies have revealed substantial sulfide-binding abilities by many vesicomyid hosts, including Calyptogena kilmeri (Barry \& Kochevar 1998), able to concentrate sulfide 5 to $10 \times$ above ambient concentrations, C. magnifica (9 to $10 \times$; Arp et al. 1984), C. elongata (30x; Childress et al. 1993), and C. pacifica (up to $60 \times$, Barry \& Kochevar 1998). It is important to remember that the sulfide measured in these species of clam is bound by the extracellular-binding component in the blood, rather than free in solution where it would be poisonous to the tissues.

As a group, thiotrophic (sulfide-utilizing) bacteria employ various enzymatic pathways for conversion of sulfide into energy, including the oxidation of sulfide, thiosulfate, sulfite, and elemental sulfur, used to fuel inorganic carbon reduction via the Calvin-Benson cycle 
(Kelly 1989, Nelson \& Hagen 1995). For endosymbionts, these pathways include the oxidation of sulfide by metal-containing proteins or by specific enzymes known as sulfide oxidases, the production of adenosine phosphosulfate from sulfite oxidation (and AMP) by APS reductase, and the production of sulfate (and ADP) from adenosine phosphosulfate by ATP sulfurylase (Fig. 1). During the process of bacterial sulfide oxidation, elemental sulfur, thiosulfate, and polysulfides can be formed as intermediate products, while sulfate is formed as an end product. The accumulation and/or presence of intermediate and end-products of sulfide oxidation in the tissues of vesicomyids can provide information about specific pathways and energy yield by symbiont sulfide oxidation. In addition, comparative measures of sulfur-containing compounds in different host species can potentially indicate differences in overall sulfide oxidation and storage capability.

To date, there have been no comparative investigations of sulfide-related physiologies between congeneric chemosynthetic associations. The high intrageneric diversity of cold seep habitats provides a unique opportunity to contrast physiological adaptations among closely related species inhabiting similar habitats, but displaying different strategies for survival. The objectives of this research project were to investigate the relationship between metabolite levels and potential sulfide utilization among 2 closely related vesicomyid bivalves inhabiting cold seeps in Monterey Bay, and to determine whether physiological differences allow for the exploitation of separate niches within the seep environment. Key physiological and biochemical processes in these associations were investigated, including sulfide uptake, binding, transport, metabolizing activity, and intermediate and endproduct formation. Although close in physical proximity, these species inhabit different sulfide regimes within the seep environment and were, therefore, expected to have divergent sulfide-related physiologies. While revealing details of the ecological physiology of Calyptogena kilmeri and C. pacifica, results from this type of study may identify general processes defining environmental and physiological boundaries for many invertebrate-bacterial symbioses.

\section{MATERIALS AND METHODS}

Specimen collection. Sediment cores and individuals of Calyptogena kilmeri and C. pacifica were collected between 1997 and 1999 from cold seep sites in Monterey Bay using MBARI's ROV 'Ventana' aboard the RV 'Pt. Lobos'. Efforts were focused on 4 sites within Monterey Bay (Fig. 2; Barry et al. 1996, Orange et al. 1999). Mount Crushmore is located in a vertically fractured region at $\sim 635 \mathrm{~m}$ depth along the walls of the Monterey Canyon. Clam Field is located near outcrops in the hydrocarbon bearing Monterey formation at 900 m depth. Clam Flat is located near an accretionary-like prism on the continental slope of the Monterey Bay at $\sim 1000 \mathrm{~m}$ depth. Invert Cliff is located in a tectonically exposed portion along the flanks of the Monterey Canyon ( $1000 \mathrm{~m}$ ) that appears to undergo active faulting.

Upon collection, each clam was removed from chilled seawater and blotted dry. Forceps were inserted gently between the shell halves (posterior) to drain water from the clam. The weight of the intact clam was determined and the shells were opened completely by severing the adductor muscles with a scalpel. Vesicomyids differ from most bivalves in having a large volume of hemoglobin-rich blood and hypertrophied gills harboring large numbers of endosymbionts. Aliquots of blood were removed from beneath the mantle via syringe for blood gas measurements, and any remaining blood was drained into cryovials and either analyzed immediately for $\mathrm{pH}$, separated into serum and hemoglobin-filled erythrocytes, or immediately flash frozen in liquid nitrogen and stored at $-80^{\circ} \mathrm{C}$. In cases where the total blood volume was weighed to determine \% blood, blood gas measurements were not made. In some cases, serum was separated from hemoglobin (whole blood) via centrifugation at $8000 \mathrm{rpm}$ for $10 \mathrm{~min}$. Gill, foot, and adductor muscle tissues were removed, weighed, and frozen at $-80^{\circ} \mathrm{C}$ for all analyses. The color and consistency of the gills is usually an indicator of health for chemosynthetic clams (Vetter 1985). Only adult clams with thick cream colored gills, a characteristic of healthy clams, were used in this study. Incidentally, some measurements were also made on 'unhealthy' clams with thin, filamentous, dark gills and these clams were lower in almost all variables measured, including blood $\sum \mathrm{CO}_{2}$, $\sum \mathrm{H}_{2} \mathrm{~S}$, protein, zinc, sulfate, and gill $\mathrm{S}^{\mathrm{o}}$ (data not shown). Whole gill demibranchs were homogenized for measures of gilll variables, to reduce the effects of intragill variability. Because Calyptogena kilmeri and C. pacifica commonly co-occur at Clam Field, all interspecies comparisons were made using data only from Clam Field. The average wet weights for clams used in this study were $30 \pm 13 \mathrm{~g}$ for $C$. kilmeri $(\mathrm{n}=78)$ and $6 \pm$ $2 \mathrm{~g}$ for C. pacifica $(\mathrm{n}=46)$.

The chemistry of interstitial fluids was characterized from sediment cores sectioned at 2 to $4 \mathrm{~cm}$ intervals. In order to collect pore water, sediment samples were centrifuged in an oxygen-free atmosphere (nitrogenpurged glove box) for $15 \mathrm{~min}$ (Barry et al. 1996). After centrifugation, pore fluid samples were transferred to gas-tight syringes and analyzed immediately for $\mathrm{pH}$ and for $\sum \mathrm{CO}_{2}$ and $\sum \mathrm{H}_{2} \mathrm{~S}$ via gas chromatography. 


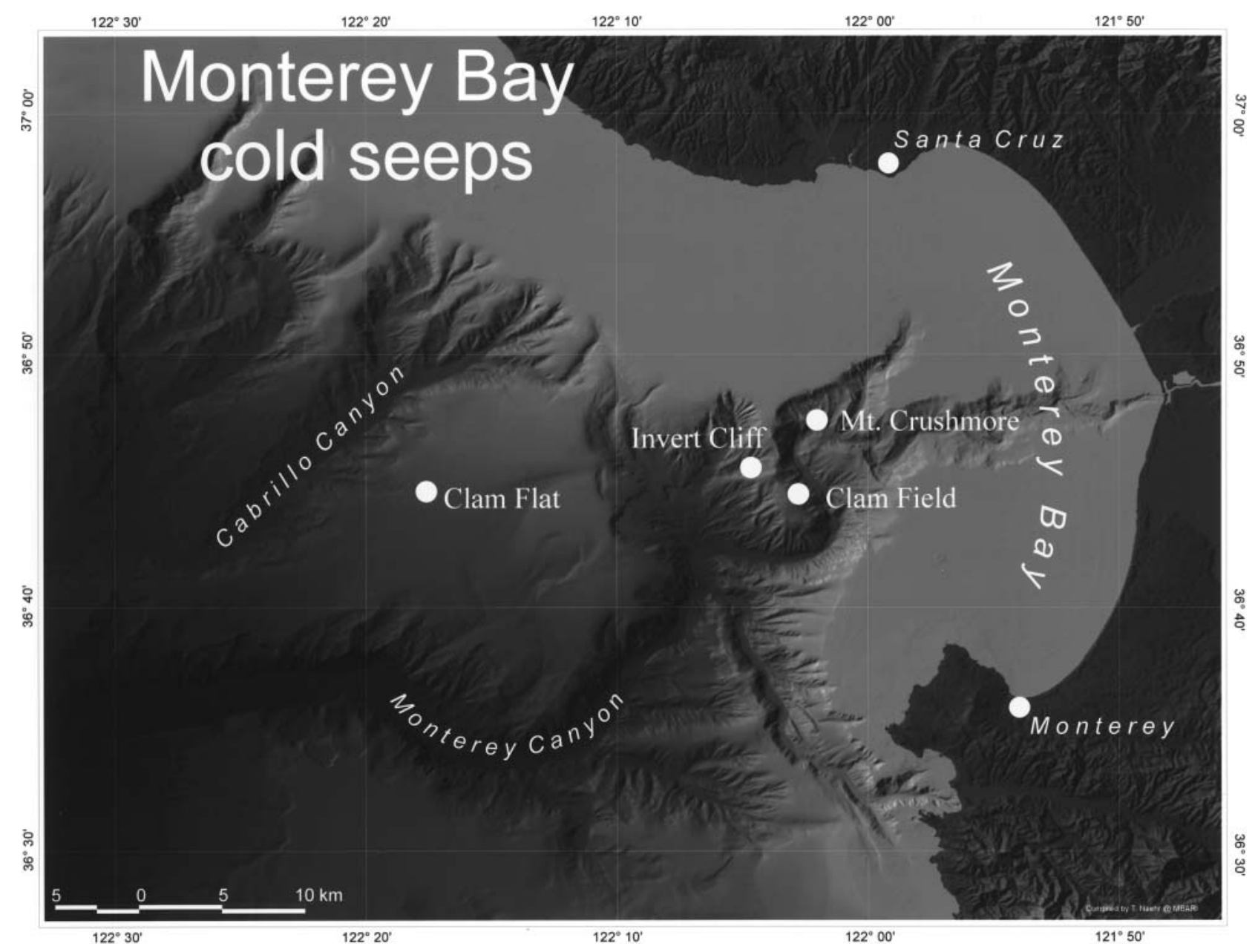

Fig. 2. Map of Monterey Bay showing cold seep locations as described in 'Materials and methods' (modified from Naehr et al. 2000, with permission)

Analyses. $\sum \mathrm{CO}_{2}\left(\mathrm{CO}_{2}+\mathrm{HCO}_{3}^{-}\right)$and $\Sigma \mathrm{H}_{2} \mathrm{~S}\left(\mathrm{HS}^{-}+\mathrm{H}_{2} \mathrm{~S}\right.$ $+\mathrm{S}^{2-}$ ) of both body fluids and pore water samples were measured in 0.1 to $0.5 \mathrm{ml}$ aliquots with a Series 5890 gas chromatograph (Hewlett Packard, Santa Clara, CA) modified for analysis of dissolved gases (Childress et al. 1984). Body fluid and pore water $\mathrm{pH}$ was measured using a flat-tip double-junction $\mathrm{pH}$ electrode (Broadley James, Irvine, CA) connected to a pH meter (Accumet 150, Denver Instrument Co., Arvada, CO). Tissue pH was measured following the methods of Pörtner et al. (1990). Briefly, tissue samples (100 to $300 \mathrm{mg}$ ) were stored at $-80^{\circ} \mathrm{C}$ and, prior to analysis, were ground to a powder under liquid nitrogen, suspended in $1.0 \mathrm{ml}$ ice cold media containing $160 \mathrm{mM}$ potassium fluoride and $1 \mathrm{mM}$ nitrilotriacetic acid, centrifuged briefly, and the supernatant was measured for $\mathrm{pH}$ using a flat-tip double-junction $\mathrm{pH}$ electrode connected to a $\mathrm{pH}$ meter.

Zinc concentrations in whole blood and serum were determined via flame atomic absorption spectrometry. Samples (30 to $40 \mu \mathrm{l}$ ) and NBS standards were diluted up to 1:1000 with $1 \%$ nitric acid and run on a Model 2380 spectrometer (Perkin Elmer, Norwalk, CT), at $213.9 \mathrm{~nm}$ wavelength, with a $0.7 \mathrm{~nm}$ slit length (according to manufacturer's standard operating conditions). Background correction resulted in no difference in the ratio of sample to standard (0.77). Protein concentration in whole blood and serum $(20 \mu \mathrm{l})$ was determined via the Lowry method (Lowry et al. 1951).

Bacterial abundance (number of symbionts per $\mathrm{mm}^{2}$ of bacteriocyte) was determined from thin sections via the methods described in Santavy et al. 1990. Abundance was measured per bacteriocyte and only in grids where entire bacteriocytes could be visualized. While we acknowledge the static nature of this technique, fluorescent methods, such as DAPI and in situ fluorescence hybridization, have proven difficult and error prone due to high autofluorescence and high mucous load of the tissues. Symbionts per mass of clam was determined using bacterial abundance estimated via TEM 2-dimensional cross-sections, \% of body mass 
devoted to symbiont-housing gill tissue, a bacterial volume of $4.2 \times 10^{-12} \mathrm{~cm}^{3}$, and a bacterial density of $1 \mathrm{~g} \mathrm{~cm}^{-3}$ (Powell \& Somero 1986). Sulfide consumption by intact gills ( 400 to $600 \mathrm{mg}$ ), as well as 1 trial with foot tissue, was measured (on the day of collection) by immersing the tissue in sulfide-rich filtered seawater (FSW) solutions. Sulfide solutions were made by dissolving $\mathrm{Na}_{2} \mathrm{~S}$ in $\mathrm{N}_{2}$-bubbled FSW (adjusted to $\mathrm{pH} 8$ with $\mathrm{HCl}$ ) and decanted into anaerobic Hungate vials. Gills were rinsed in cold FSW before being added to the vials. After adding the tissue, vials were capped (with septum caps) and pressurized to 10 psi with a 20: $80 \% \mathrm{CO}_{2}: \mathrm{N}_{2}$ gas mix. Final conditions achieved were 3 to $5 \mathrm{mM} \mathrm{CO}_{2}, 0.4$ to $0.9 \mathrm{mM} \mathrm{H}_{2} \mathrm{~S}$, and $\mathrm{pH}$ 6.7. The ratio of incubation medium to gill was always between 20:1 and $40: 1$. The Hungate tubes were rotated at $4^{\circ} \mathrm{C}$ for up to $64 \mathrm{~h}$ and incubation medium was removed via syringe every 6 to $19 \mathrm{~h}$ and analyzed for $\sum \mathrm{H}_{2} \mathrm{~S}$ via gas chromatography (described above). Vials without tissue were included as controls and showed a loss of only $5 \mu \mathrm{mol} \mathrm{H} \mathrm{H}_{2} \mathrm{~S} \mathrm{~h}^{-1}$ ( 0.5 to $1 \%$ ). Rates of sulfide uptake were calculated as the difference between the 2 treatments, for each tissue.

Methods for enzyme analyses have been described in detail elsewhere (Peck et al. 1965, Felbeck 1981, Powell \& Somero 1985, Renosto et al. 1991, Hagen \& Nelson 1997). Briefly, enzyme assays were performed at $25^{\circ} \mathrm{C}$ using a UV160U spectrophotometer (Shimadzu, Columbia, MD). Activities were measured in quartz cuvettes under non-limiting substrate conditions (determined empirically). For all assays, Triton X-100 increased the activity (up to $65 \%$ ), while centrifugation caused a loss in activity (up to $75 \%$ ). For all enzyme assays, activity is expressed as $\mu \mathrm{mol}$ substrate utilized per min per g wet weight. Final activities were calculated as the difference between unboiled and boiled samples. Non-enzymatic (heat insensitive) activity accounted for up to $40 \%$ of the measured sulfide oxidase activity, and up to $20 \%$ of both APS reductase and ATP sulfurylase activity. Sulfide oxidase was measured by following a decrease in the reduction of benzyl viologen by sulfide (Powell \& Somero 1985). Tissue (100 to $400 \mathrm{mg})$ was homogenized $(1: 100)$ in $50 \mathrm{mM}$ Tris- $\mathrm{HCl}$ (pH 8.0 at $20^{\circ} \mathrm{C}$ ) containing $0.1 \%$ Triton X-100, on ice. From this crude homogenate, $50 \mu \mathrm{l}$ was added to $950 \mu \mathrm{l}$ assay mixture containing $40 \mathrm{mM}$ glycine buffer $(\mathrm{pH} 9.0$ at $20^{\circ} \mathrm{C}$ ), $2 \mathrm{mM}$ benzyl viologen, and $5 \mathrm{mM}$ sodium sulfide. Activity was measured as an increase in absorbance at $578 \mathrm{~nm}$ using the extinction coefficient of $8.65 \mathrm{OD} \mu \mathrm{mol}^{-1} \mathrm{ml}^{-1}$. For APS reductase and ATP sulfurylase, tissue was homogenized (1:100) in $100 \mathrm{mM}$ Tris- $\mathrm{HCl}\left(\mathrm{pH} 7.4\right.$ at $\left.5^{\circ} \mathrm{C}\right)$ containing $1 \%$ Triton X-100, on ice. APS reductase was measured by following the reduction of ferricyanide (modified from Peck et al. 1965, Hagen \& Nelson 1997). From this crude homo- genate, $50 \mu \mathrm{l}$ was added to $900 \mu \mathrm{l}$ assay mixture containing $50 \mathrm{mM}$ Tris- $\mathrm{HCl}(\mathrm{pH} 7.5), 1 \mathrm{mM} \mathrm{K} \mathrm{Fe}_{3}(\mathrm{CN})_{6}$, $0.25 \mathrm{mM}$ EDTA, and $3 \mathrm{mM}$ AMP. The reaction was initiated by adding $100 \mu \mathrm{l}$ sulfite ( $6 \mathrm{mM}$ final concentration). Activity was measured as a decrease in absorbance at $420 \mathrm{~nm}$ using the extinction coefficient of $1.01 \mathrm{OD} \mu \mathrm{mol}^{-1} \mathrm{ml}^{-1}$. ATP sulfurylase was measured by following the reduction of $\mathrm{NADP}^{+}$in a reaction coupled to hexokinase and glucose-6-phosphate dehydrogenase (modified from Felbeck 1981, Renosto et al. 1991, Hagen \& Nelson 1997). From this crude homogenate, $50 \mu \mathrm{l}$ was added to $950 \mu \mathrm{l}$ assay mixture containing $100 \mathrm{mM}$ Tris- $\mathrm{HCl}$ ( $\mathrm{pH} 7.5), 8 \mathrm{mM} \mathrm{MgCl}_{2}, 25 \mathrm{mM}$ glucose, $0.65 \mathrm{mM} \mathrm{NADP}^{+}, 10 \mathrm{U} \mathrm{ml}^{-1}$ yeast hexokinase, and $5 \mathrm{U} \mathrm{ml}^{-1}$ yeast glucose-6-phosphate dehydrogenase. The reaction was initiated by adding $50 \mu \mathrm{l}$ of a solution containing $0.5 \mathrm{mM}$ adenosine-5-phosphosulfate (APS) and $25 \mathrm{mM}$ sodium pyrophosphate. Activity was measured as an increase in absorbance at $340 \mathrm{~nm}$ using the extinction coefficient of $6.1 \mathrm{OD} \mu \mathrm{mol}^{-1} \mathrm{ml}^{-1}$.

Elemental sulfur was measured via colorimetric cyanolysis (Bartlett \& Skoog 1954, Schedel \& Truper 1980). Elemental sulfur reacts rapidly with cyanide to produce thiocyanate, which can be measured by the addition of a ferric ion solution. Tissue (40 to $100 \mathrm{mg}$ ) was homogenized $(1: 1000)$ in deionized water to achieve $\mathrm{S}^{\circ}<1 \mathrm{mg} \mathrm{ml}^{-1}$, and filtered through $0.2 \mu \mathrm{m}$ polycarbonate filters. Filters were placed in $15 \mathrm{ml}$ vials with $3 \mathrm{ml} 0.025 \mathrm{M} \mathrm{NaCN}$ (in $50 \%$ acetone), incubated for $10 \mathrm{~min}$ at $90^{\circ} \mathrm{C}$, vortexed, and allowed to cool to room temperature. After cooling, $6.5 \mathrm{ml} \mathrm{DI}$ and $0.5 \mathrm{ml}$ $0.75 \mathrm{M} \mathrm{Fe}\left(\mathrm{NO}_{3}\right)_{3}$ (in $20 \% \mathrm{HNO}_{3}$ ) were added and the absorbance was read at $460 \mathrm{~nm}$. Absorbance values of samples were compared against known $\mathrm{S}^{\circ}$ standards. Sulfur values are expressed as a percentage of gill wet weight. Polysulfides were measured via high-performance liquid chromatography according to the methods of Lauren \& Watkinson (1985) and Vismann (1991). Tissue (200 to $600 \mathrm{mg}$ ) was homogenized $(1: 4)$ in deionized water, diluted 1:9 in methanol:chloroform (1:1), and extracted overnight at room temperature. Extracted samples were centrifuged and the supernatant was evaporated and resuspended in methanol (the solubility of sulfur in $\mathrm{MeOH}$ is $<100 \mu \mathrm{g} \mathrm{ml}^{-1}$ ). From this, $20 \mu \mathrm{l}$ samples were injected through a guard column to a Hamilton PRP-1 reversed phase column (10 $\mu \mathrm{m}$ styene-divinlybenzene packing material), using 1:1 methanol:chloroform, pumped at $1 \mathrm{ml} \mathrm{min}^{-1}$, as the eluent. Sulfur-containing compounds were detected at $254 \mathrm{~nm}$ using a UV/VIS detector (Shimadzu VP series). Polysulfides are also expressed as a percentage of gill wet weight. Sulfate concentrations were determined using single column ion chromatography (Girard \& Glatz 1981, Sanders \& Childress 1991). Body fluid and pore water samples were thawed (if previously frozen), 
deproteinated by dilution with methanol $(1: 1)$, and centrifuged at $8000 \mathrm{rpm}$ for $10 \mathrm{~min}$. Standard solutions were diluted in the same manner. For gill tissue, samples were homogenized in a glass homogenizer (1:9 with eluent), then diluted with methanol and centrifuged, as above for fluid samples. All samples were diluted again to a final dilution of 1:20, with HPLCgrade water. Using a Wescan anion column (Alltech, Deerfield, IL) and a Shimadzu HPLC system (VP series), $20 \mu \mathrm{l}$ samples were analyzed. The eluent was $4 \mathrm{mM}$ potassium hydrogen phthalic acid (filtered at $0.45 \mu \mathrm{m})$, pumped at $2.5 \mathrm{ml} \mathrm{min}^{-1}$. Ions were detected using a conductivity detector (Shimadzu). Thiosulfate was also measurable using this method, however, the lower sensitivity limit was $1 \mathrm{mM}$. In previous studies on 2 vesicomyid clams (Calyptogena magnifica and $C$. elongata), freshly collected clams demonstrated thiosulfate levels of 0.04 to $1.5 \mathrm{mM}$ and in lab manipulated experiments thiosulfate concentrations reached up to $1 \mathrm{mM}$ in the blood (Childress et al. 1991, 1993). These concentrations were below our detection limit and may or may not be significant for the clams in our study.

\section{RESULTS}

\section{Internal and environmental metabolite levels}

Levels of $\sum \mathrm{H}_{2} \mathrm{~S}$ in body fluids of Calyptogena kilmeri and C. pacifica varied among sites in relation to changes in environmental sulfide levels. Intraspecific comparison of internal sulfide levels to environmental sulfide levels measured in this study and in Barry et al. (1997) revealed a significant positive correlation between internal $\Sigma \mathrm{H}_{2} \mathrm{~S}$ levels in both species with site $\Sigma \mathrm{H}_{2} \mathrm{~S}$ from Mount Crushmore (external sulfide of $\sim 0.1 \mathrm{mM}$ ) and Clam Field (external sulfide of $\sim 4 \mathrm{mM}_{\text {; }}$ Fig. 3). Individuals of C. pacifica collected from Clam Field had significantly higher internal sulfide $(2.72 \mathrm{mM}$ $\left.\mathrm{H}_{2} \mathrm{~S}\right)$ than those from Mount Crushmore $\left(0.27 \mathrm{mM} \mathrm{H}_{2} \mathrm{~S}_{\text {; }}\right.$ Mann-Whitney $\mathrm{p}=0.029$ ). Likewise, individuals of C. kilmeri collected from Clam Field also had significantly higher internal sulfide $\left(1.05 \mathrm{mM} \mathrm{H}_{2} \mathrm{~S}\right)$ than those from Mount Crushmore $\left(0.26 \mathrm{mM} \mathrm{H}_{2} \mathrm{~S}_{\text {; }}\right.$ Mann-Whitney $p=0.035$ ). No additional increase in internal sulfide (above Clam Field levels) was observed in C. kilmeri collected from Invert Cliff or Clam Flat, both with higher average external sulfide levels ( 7 to $18 \mathrm{mM}$ ). For both species, no correlation between internal and environmental $\Sigma \mathrm{CO}_{2}, \mathrm{pH}$ or $\mathrm{SO}_{4}$ was observed.

Interspecific differences in blood $\Sigma \mathrm{CO}_{2}$ and $\Sigma \mathrm{H}_{2} \mathrm{~S}$ in Calyptogena kilmeri and C. pacifica were also observed. Blood $\Sigma \mathrm{CO}_{2}$ and $\Sigma \mathrm{H}_{2} \mathrm{~S}$ levels were significantly higher in C. pacifica than in C. kilmeri collected from Clam Field (Mann-Whitney p < 0.04; Table 1). Blood,

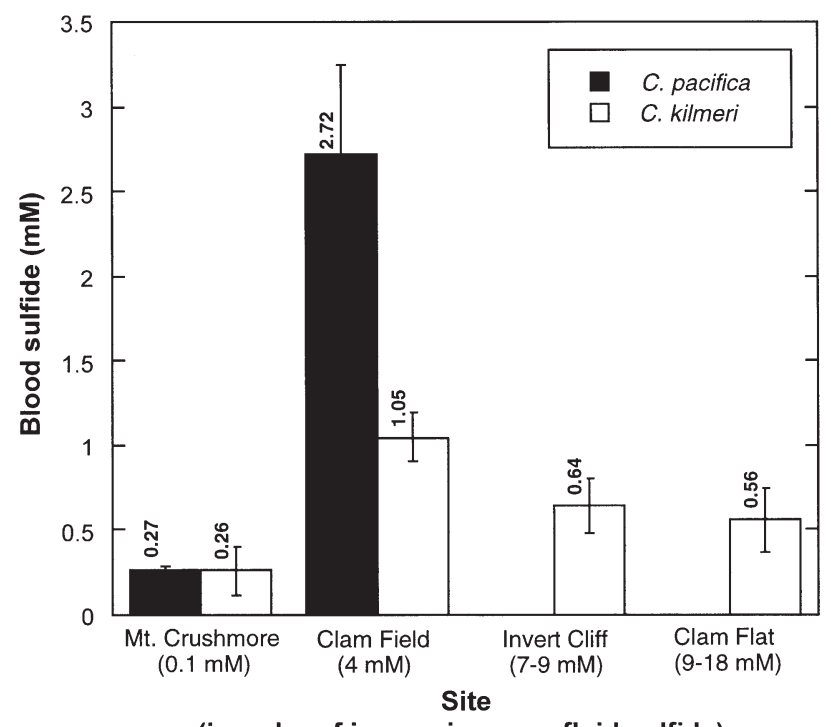

(in order of increasing pore fluid sulfide)

Fig. 3. Concentrations (mean $\pm 1 \mathrm{SE}$ ) of internal $\left(\mathrm{H}_{2} \mathrm{~S}\right.$ in Calyptogena pacifica and C. kilmeri, collected from 4 seep sites within Monterey Bay; Mount Crushmore $\left(0.1 \mathrm{mM} \mathrm{H}_{2} \mathrm{~S}\right)$, Clam Field $\left(\sim 4 \mathrm{mM} \mathrm{H}_{2} \mathrm{~S}\right)$, Invert Cliff $\left(\sim 7\right.$ to $\left.9 \mathrm{mM} \mathrm{H}_{2} \mathrm{~S}\right)$, and Clam Flat ( $\sim 9$ to $18 \mathrm{mM} \mathrm{H}_{2} \mathrm{~S}$ ). Internal values were measured during this study, while environmental data from our study was compiled with those of Barry et al. 1997. n for C. pacifica $=3$, Mount Crushmore; 12, Clam Field. n for C. kilmeri = 3, Mount Crushmore; 25, Clam Field; 14, Invert Cliff; 8, Clam Flat

foot, and gill $\mathrm{pH}$ values, however, did not differ significantly among tissues between species (MannWhitney $\mathrm{p}>0.25$ ) or within species (Wilcoxon $\mathrm{p}>0.14$; Table 1). The Mann-Whitney $U$-test was used to evaluate interspecies differences while the Wilcoxon signed-rank tests was used to test for differences within species. Blood $\mathrm{pH}$ values were $7.02 \pm 0.13$ for $C$. pacifica and $6.91 \pm 0.08$ for C. kilmeri (Table 1). Foot and gill $\mathrm{pH}$ values were $7.04 \pm 0.02(\mathrm{n}=6)$ and $6.93 \pm$ $0.04(\mathrm{n}=2)$ respectively, for C. pacifica, and $6.93 \pm 0.02$ $(\mathrm{n}=15)$ and $6.88 \pm 0.01(\mathrm{n}=12)$, respectively, for $C$. kilmeri. In addition, higher internal sulfide levels were significantly correlated with lower internal $\mathrm{pH}$ values

Table 1. $\sum \mathrm{CO}_{2}, \sum \mathrm{H}_{2} \mathrm{~S}$, and $\mathrm{pH}$ (mean $\pm \mathrm{SD}$ ) of blood from Calyptogena kilmeri and C. pacifica collected from Clam Field. p-value $=$ Mann-Whitney $U$-test; used to evaluate differences in distribution between data sets from Calyptogena kilmeri and C. pacifica. $\mathrm{n}$ in parentheses

\begin{tabular}{|lccc|}
\hline Species & $\begin{array}{c}\sum \mathrm{CO}_{2} \\
\left(\mathrm{mmol} \mathrm{l}^{-1}\right)\end{array}$ & $\begin{array}{c}\sum \mathrm{H}_{2} \mathrm{~S} \\
\left(\mathrm{mmol} \mathrm{l}^{-1}\right)\end{array}$ & $\mathrm{pH}$ \\
\hline C. kilmeri & $3.3 \pm 0.8(19)$ & $1.1 \pm 0.8(19)$ & $6.91 \pm 0.08(17)$ \\
C. pacifica & $4.7 \pm 2.3(12)$ & $2.7 \pm 2.0(12)$ & $7.02 \pm 0.13(12)$ \\
p-value & 0.044 & 0.004 & 0.268 \\
\hline
\end{tabular}


Table 2. Blood sulfide, pH levels, and ratios of pH to sulfide for freshly collected Calyptogena kilmeri and C. pacifica. Both sulfide and $\mathrm{pH}$ values represent the range for all animals from each collection (represented by Julian date). There were 5 separate collections for Calyptogena kilmeri and 3 separate collections for C. pacifica. $\Delta \mathrm{pH}$ :sulfide (slope) was determined by plotting all clams from each collection. $\mathrm{n}=$ no. of clams collected. $\mathrm{p}$-value $=$ significance of linear regression; used to determine linear relationships between $\mathrm{pH}$ and sulfide values

\begin{tabular}{|c|c|c|c|c|c|}
\hline $\begin{array}{l}\text { Species } \\
\text { Julian date }\end{array}$ & $\mathrm{n}$ & $\begin{array}{l}\text { Blood sulfide } \\
\left(\mathrm{mmol} \mathrm{l}^{-1}\right)\end{array}$ & Blood pH & $\Delta \mathrm{pH}$ :sulfide slope & $\mathrm{p}$-value \\
\hline \multicolumn{6}{|l|}{ C. kilmeri } \\
\hline 99068 & 3 & $1.77-2.19$ & $6.93-7.04$ & -0.268 & 0.09 \\
\hline 99092 & 9 & $0.00-1.12$ & $6.65-6.86$ & -0.166 & 0.003 \\
\hline 99147 & 5 & $0.16-0.95$ & $6.80-7.06$ & -0.274 & 0.09 \\
\hline 99264 & 7 & $0.10-0.97$ & $6.62-6.93$ & -0.099 & 0.48 \\
\hline 99272 & 7 & $0.00-2.61$ & $6.85-6.93$ & -0.015 & 0.36 \\
\hline \multicolumn{6}{|l|}{ C. pacifica } \\
\hline 99068 & 4 & $0.99-5.23$ & $6.85-7.30$ & -0.013 & 0.83 \\
\hline 99272 & 4 & $0.24-6.94$ & $6.92-7.10$ & -0.003 & 0.77 \\
\hline 99309 & 4 & $0.54-4.68$ & $6.85-7.03$ & -0.023 & 0.48 \\
\hline
\end{tabular}

in 3 of 5 separate $C$. kilmeri collections ( $\mathrm{n}=3$ to 9 per collection, regression $\mathrm{p}<0.01$ ), with a $1 \mathrm{mM}$ higher sulfide concentration corresponding to a 0.22 unit lower $\mathrm{pH}$ (Table 2). A negative correlation between internal $\mathrm{pH}$ and internal sulfide levels was not observed in C. pacifica (3 separate collections, $\mathrm{n}=4$ each, Table 2).

\section{Uptake and transport of sulfide}

Although the abundance of bacteria in gill tissues (as a fraction of total body mass) varied considerably within species (20 to $40 \%$ by volume), clear differences in symbiont loads were detected between species. Despite intraspecific variability, the abundance of bacteria in Calyptogena pacifica $\left(110.4 \times 10^{-4} \mathrm{~g}\right.$ bacteria per $\mathrm{g}$ clam, normalized to a $6 \mathrm{~g}$ average soft tissue weight) was significantly greater than in $C$. kilmeri $\left(13.2 \times 10^{-4} \mathrm{~g}\right.$ bacteria per $\mathrm{g}$ clam, normalized to a $30 \mathrm{~g}$ average soft tissue weight, Mann-Whitney $\mathrm{p}=0.003)$.

Calyptogena pacifica showed significantly higher rates of sulfide consumption by intact gills $(0.96 \mu \mathrm{mol}$ per g gill per min) than C. kilmeri (0.13 $\mu$ mol per g gill per min; Table 3, Mann-Whitney $\mathrm{p}=0.014$ ). These gillspecific sulfide consumption rates extrapolate to whole clam consumption rates of $\sim 11 \mu \mathrm{mol}$ per g clam per $\mathrm{h}$ and $\sim 2 \mu \mathrm{mol}$ per gclam per $\mathrm{h}$ for $C$. pacifica and $C$. kilmeri, respectively, based on \% gill (19.1 and 20.4\%) and average wet tissue mass (6 and $30 \mathrm{~g}$; Table 3 ). These extrapolations are supported by previously determined correlations between sulfide consumption in whole clams and symbiont-containing tissues in the vent tubeworm Riftia pachyptila (Childress et al. 1991).
Table 3. Sulfide consumption (mean $\pm \mathrm{SD}$ ) in gill tissue for Calyptogena kilmeri and C. pacifica from Clam Field. $\mathrm{n}$ in parentheses. Gill-specific sulfide consumption rates were extrapolated to whole clam consumption rates of $\sim 2$ and $\sim 11$ umol per g clam per h for Calyptogena kilmeri and C. pacifica, based on \% gill (19.1 and $20.4 \%$ ) and average wet tissue mass ( 6 and $30 \mathrm{~g}$ ), respectively. Sulfide consumption by $C$. kilmeri foot tissue was very low, measuring only $0.02 \mu \mathrm{mol}$ per g gill per min, approximately $2 \%$ of the gill consumption rate. p-value $=$ Mann-Whitney $U$-test

\begin{tabular}{|c|c|c|}
\hline \multicolumn{3}{|c|}{ Gill sulfide consumption } \\
\hline C. kilmeri & $0.13 \pm 0.02(5)$ & 2 \\
\hline C. pacifica & $0.96 \pm 0.16(4)$ & 11 \\
\hline $\mathrm{p}$-value & 0.014 & \\
\hline
\end{tabular}

Calyptogena pacifica demonstrated a greater potential for sulfide uptake than C. kilmeri, owing to larger foot volume, blood volume, and a higher concentration of zinc. C. pacifica devoted a significantly larger \% of total body mass to both foot and blood (6.8 and 36.8\%) than C. kilmeri (6.0 and 32.5\%; Mann-Whitney p $<0.1$, Table 4). In addition, C. pacifica had a significantly higher blood zinc concentration $(7.2 \pm 0.8 \mathrm{mM})$ than $C$. kilmeri $(4.8 \pm 0.4 \mathrm{mM}$; Mann-Whitney $\mathrm{p}=0.022)$. No difference in zinc concentration between whole blood and serum was detected for either species. In both species, zinc levels were correlated positively with internal $\sum \mathrm{H}_{2} \mathrm{~S}$ levels (regression $\mathrm{p}<0.0001$ for $C$. kilmeri $(\mathrm{n}=33$ ) and regression $\mathrm{p}=0.08$ for $C$. pacifica $(\mathrm{n}=8)$; Fig. 4), suggesting that zinc is likely involved in sulfide binding in these 2 species as well. Zinc/sulfide ratios for C. pacifica and C. kilmeri, were 3.5 and 5.2, respectively (data from Fig. 4). Total blood protein was com- 
Table 4. Foot mass, blood mass, blood zinc concentration and blood protein concentration (mean \pm SD) in Calyptogena kilmeri and C. pacifica from Clam Field. $\mathrm{n}$ in parentheses. $\mathrm{p}$-value $=$ Mann-Whitney $U$-test

\begin{tabular}{|lcccc|}
\hline & $\begin{array}{c}\text { Foot mass } \\
(\% \text { of total biomass })\end{array}$ & $\begin{array}{c}\text { Blood mass } \\
(\% \text { of total biomass })\end{array}$ & $\begin{array}{c}\text { Zinc } \\
\left(\mathrm{mmol} \mathrm{l}^{-1}\right)\end{array}$ & $\begin{array}{c}\text { Protein } \\
\left(\mathrm{mg} \mathrm{ml}^{-1}\right)\end{array}$ \\
\hline C. kilmeri & $6.0 \pm 0.8(10)$ & $32.5 \pm 4.6(10)$ & $4.8 \pm 0.4(21)$ & $31.3 \pm 1.6(9)$ \\
C. pacifica & $6.8 \pm 0.8(10)$ & $36.8 \pm 6.0(10)$ & $7.2 \pm 0.8(10)$ & $33.2 \pm 1.7(10)$ \\
p-value & 0.041 & 0.096 & 0.022 & 0.480 \\
\hline
\end{tabular}

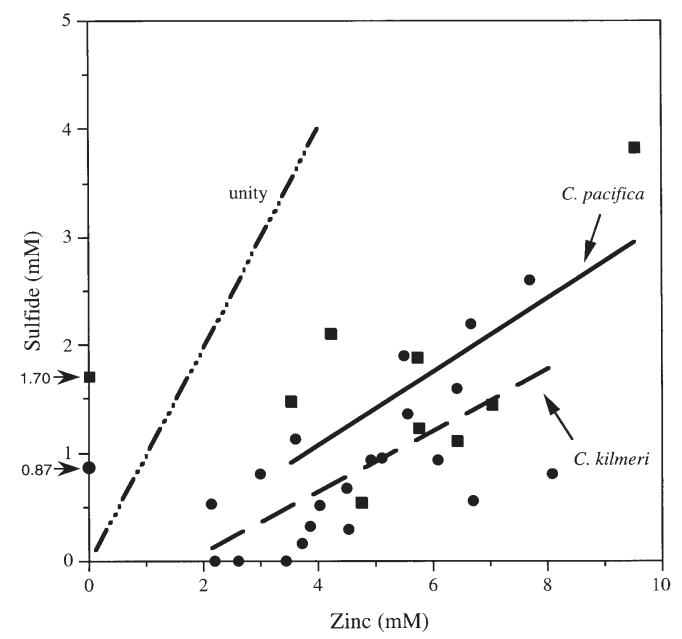

Fig. 4. Relationship between hemolymph zinc and sulfide concentrations in both Calyptogena pacifica $(\mathbf{\square}, \mathrm{n}=10, y=$ $-0.300+0.341 x, r=0.65, p=0.0804$, regression significance) and $C$. kilmeri $(\bullet, \mathrm{n}=21, \mathrm{y}=-0.488+0.284 x, \mathrm{r}=0.68, \mathrm{p}=$ 0.0008 , regression significance) from Clam Field. The average internal sulfide levels for all individuals included are $1.70 \mathrm{mM}$ for C. pacifica and $0.87 \mathrm{mM}$ for C. kilmeri (as shown on the $y$-axis)

parable in both species ( 31 to $33 \mathrm{mg} \mathrm{ml}^{-1}$, MannWhitney $\mathrm{p}=0.48$, Table 4 ). Protein in whole blood did not correlate with internal levels of either $\mathrm{\Sigma H}_{2} \mathrm{~S}$ (regression $\mathrm{p}=0.14$ ) or zinc (regression $\mathrm{p}=0.10$ ), suggesting that the binding component is likely not proteinaceous.

Table 5. Activities of sulfur metabolism enzymes (mean \pm SD) in the gill tissue of Calyptogena kilmeri and C. pacifica from Clam Field. $\mathrm{n}$ in parentheses. References: *Arp et al. 1984, Fisher et al. 1988, ${ }^{\circledR}$ Powell \& Somero 1985, Somero et al. 1989; ${ }^{\ddagger}$ Brooks et al. 1987, Somero et al. 1989. $\mathrm{nm}=$ not measured. $\mathrm{p}$-value $=$ Mann-Whitney $U$-test

\begin{tabular}{|lccc|}
\hline & $\begin{array}{c}\text { Sulfide oxidase } \\
\left(\mu \mathrm{mol} \mathrm{g} \mathrm{min}^{-1}\right)\end{array}$ & $\begin{array}{c}\text { APS reductase } \\
\left(\mu \mathrm{mol} \mathrm{g} \mathrm{min}^{-1}\right)\end{array}$ & $\begin{array}{c}\text { ATP sulfurylase } \\
\left(\mu \mathrm{mol} \mathrm{g}^{-1} \mathrm{~min}^{-1}\right)\end{array}$ \\
\hline C. kilmeri & $4.1 \pm 1.2(11)$ & $19.4 \pm 6.5(8)$ & $12.1 \pm 3.3(9)$ \\
C. pacifica & $6.7 \pm 2.1(9)$ & $38.9 \pm 11.0(7)$ & $9.6 \pm 4.8(9)$ \\
p-value & 0.003 & 0.001 & 0.233 \\
Lucinoma sp. $^{*}$ & 2 & $0-2$ & $3-9$ \\
Solemya reidi $^{\text {ॠ }}$ & 5 & 4 & 77 \\
C. magnifica $^{*}$ & 6 & $\mathrm{~nm}$ & 5 \\
\hline
\end{tabular}

\section{Sulfur metabolizing activity}

Measurements of enzymatic activity indicated that Calyptogena pacifica has a greater capacity for sulfide oxidation. C. pacifica possessed a significantly higher sulfide oxidase activity in gill tissue $\left(6.7 \pm 2.1 \mu \mathrm{mol} \mathrm{g}{ }^{-1}\right.$ $\left.\min ^{-1}\right)$ than C. kilmeri $\left(4.1 \pm 1.2 \mu \mathrm{mol} \mathrm{g}^{-1} \mathrm{~min}^{-1}\right.$; MannWhitney $\mathrm{p}=0.003$, Table 5), although both $C$. kilmeri and $C$. pacifica had sulfide oxidase activities that were comparable to other host species (2 to $8 \mu \mathrm{mol} \mathrm{g}{ }^{-1} \mathrm{~min}^{-1}$ from Solemya reidi, C. magnifica, and a seep clam of the family Lucinidae; Powell \& Somero 1985; Brooks et al. 1987; Fisher et al. 1988). Sulfide oxidase activity in foot tissue, which probably serves a protective role in peripheral detoxification, was comparable between C. kilmeri and C. pacifica $\left(1.3 \mu \mathrm{mol} \mathrm{g}^{-1} \mathrm{~min}^{-1}\right)$. APS reductase activity was also significantly higher in $C$. pacifica $\left(38.9 \pm 11.0 \mu \mathrm{mol} \mathrm{g}^{-1} \mathrm{~min}^{-1}\right)$ than C. kilmeri $\left(19.4 \pm 6.5 \mu \mathrm{mol} \mathrm{g}{ }^{-1} \mathrm{~min}^{-1}\right.$; Mann-Whitney $\mathrm{p}=0.001$, Table 5), as well as many other bivalves measured previously, including $S$. reidi and Lucinoma floridana (2 to $4 \mu \mathrm{mol} \mathrm{g}{ }^{-1} \mathrm{~min}^{-1}$; Felbeck 1981; Somero et al. 1989), while APS reductase activity in foot tissue was negligible for both species. Activity of ATP sulfurylase, however, did not differ significantly between $C$. kilmeri and C. pacifica ( 10 to $12 \mu \mathrm{mol} \mathrm{g} \mathrm{min}^{-1}$, Mann-Whitney $\mathrm{p}=0.233$, Table 5 ), or among other species (3 to $77 \mu \mathrm{mol} \mathrm{g}{ }^{-1} \mathrm{~min}^{-1}$; Arp et al. 1984, Brooks et al. 1987, Somero et al. 1989). Activities of the different enzymes in C. kilmeri and C. pacifica were not correlated with each other (regression $\mathrm{p}>0.35$ ), which is similar to results from previous studies (Fisher et al. 1988).

\section{Products of sulfide oxidation}

Previous TEM studies have shown that vesicomyid symbionts produce sulfur vesicles thought to contain elemental sulfur, polysulfides, or polythionates (Vetter 1985, Shively et al. 1988). We observed the presence of elemental sulfur and polysulfides in both clam species. Elemental sulfur 
Table 6. Elemental sulfur $\left(\mathrm{S}^{\circ}\right)$, polysulfide, and sulfate levels (mean $\pm \mathrm{SD}$ ) in gill tissue and blood of Calyptogena kilmeri and C. pacifica from Clam Field. $\mathrm{n}$ in parentheses. p-value $=$ Mann-Whitney $U$-test

\begin{tabular}{|lcccc|}
\hline & $\begin{array}{c}\text { Gill } \mathrm{S}^{\circ} \\
(\% \text { of gill) }\end{array}$ & $\begin{array}{c}\text { Gill polysulfides } \\
(\% \text { of gill) }\end{array}$ & $\begin{array}{c}\text { Gill sulfate } \\
\left(\mathrm{mmol} \mathrm{l}^{-1}\right)\end{array}$ & $\begin{array}{c}\text { Blood sulfate } \\
\left(\mathrm{mmol} \mathrm{l}^{-1}\right)\end{array}$ \\
\hline C. kilmeri & $4.7 \pm 2.4(11)$ & $0.6 \pm 0.1(4)$ & $13.2 \pm 1.2(7)$ & $24.6 \pm 1.1(7)$ \\
C. pacifica & $2.4 \pm 1.2(8)$ & $0.3 \pm 0.1(6)$ & $14.4 \pm 2.1(7)$ & $24.1 \pm 1.4(7)$ \\
p-value & 0.008 & 0.055 & 0.482 & 0.378 \\
\hline
\end{tabular}

sites. For both species, it appears that internal sulfide levels reflect the environment in which the clam is found. For C. pacifica, internal sulfide was significantly greater in samples from Clam Field than those from Mount Crushmore. This relationship, also seen to a lesser extent in C. kilmeri, has been observed previously in the tubeworm Riftia pachyptila, in which internal $\mathrm{H}_{2} \mathrm{~S}$ levels were linked to the

levels were higher in Calyptogena kilmeri $(4.7 \pm 2.4 \%$ of gill, by mass) than C. pacifica $(2.4 \pm 1.2 \%$ of gill; Mann-Whitney $\mathrm{p}=0.008$, Table 6). Likewise, the percentages of polysulfides in gill tissue were also higher in C. kilmeri $(0.6 \%)$ than C. pacifica (0.3\%, MannWhitney $\mathrm{p}=0.055$, Table 6 ), however, as a percentage of the total sulfur content of the gill, C. pacifica and $C$. kilmeri contained similar amounts of polysulfides (13\% by mass). Sulfate levels in both gill and blood did not differ between the 2 species (Mann-Whitney $\mathrm{p}>0.38$, Table 6). No other intermediate sulfide oxidation products were detected using our methods.

\section{DISCUSSION}

Significant variation in the sulfide physiology of 2 congeneric vesicomyid clams, Calyptogena kilmeri and $C$. pacifica, are associated with differences in the microhabitat chemistry inhabited by each, and suggest that these differences result from their adaptations to contrasting environmental regimes. The first step in harnessing the reducing power of sulfide depends upon the uptake of sulfide by the intact symbioses, as well as the transport of sulfide from the host tissues to the symbionts, while the second step depends upon the conversion of sulfide to energy by the bacteria. C. pacifica inhabits areas of lower sulfide, yet must effectively maintain a supply of sulfide to its internal symbionts. We observed C. pacifica to be physiologically poised for the uptake of sulfide from lower external concentrations. Our results show clearly that $C$. pacifica has a higher potential for both the uptake and transport of sulfide, as well as sulfur metabolism by the symbionts. Conversely, C. kilmeri has a specific need for higher environmental sulfide levels because of a less effective sulfide uptake mechanism. We suggest that $C$. pacifica and $C$. kilmeri employ opposing sulfide strategies and that species-specific physiological variations allow for exploitation of separate microniches within the seep environment.

Although significant variation exists between Calyptogena pacifica and C. kilmeri, internal sulfide levels within species were generally correlated with variation in environmental sulfide levels observed among
$\mathrm{SH}_{2} \mathrm{~S}$ concentration of vent source waters (Goffredi et al. 1997, S.K.G. unpubl. data). Similarly, significant intersite variation in internal sulfide levels has also been reported for C. magnifica, and may result from microhabitat variability (Arp et al. 1984). These results suggest that sulfide acquisition in these host species may be opportunistic and partially, if not largely, dependent upon external levels.

In vivo $\mathrm{H}_{2} \mathrm{~S}$ concentrations can reach very high levels in hosts of sulfide-oxidizing symbionts; however, sulfide in the body fluids of chemoautotrophic bivalves, as well as inorganic carbon and $\mathrm{pH}$, have not been well studied. The only previous measurements with freshly collected vesicomyids have been on the vent clam Calyptogena magnifica, which demonstrated 0.3 to

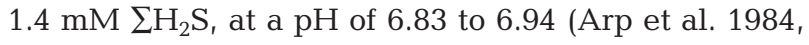
Childress et al. 1991). Measures of internal sulfide levels in C. elongata $(1.7 \mathrm{mM})$ from the Santa Barbara

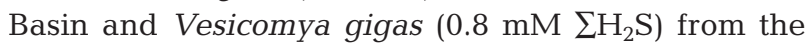
Monterey Canyon were comparable (S.K.G. pers. obs.). Internal sulfide concentrations measured in C. pacifica ( $2.7 \mathrm{mM}$ average) are the highest of any bivalve reported to date. High sulfide concentrations in C. pacifica are perhaps not surprising considering its enhanced ability to exploit variable environmental conditions.

Variation in internal sulfide levels are typically associated with changes in internal $\mathrm{pH}$, postulated to arise from proton release during dissociation and sulfide binding by the extracellular-binding component. Lower blood pH observed in Calyptogena kilmeri with higher total internal sulfide was similar to results from laboratory studies on other vesicomyids (C. magnifica and $C$. elongata), in which increases in internal sulfide resulted in decreased internal $\mathrm{pH}$ (Childress et al. 1991, 1993). In contrast to these results, however, blood $\mathrm{pH}$ in C. pacifica in our study was not correlated with internal sulfide levels. All vesicomyids probably have a similar mechanism for sulfide binding by the specialized serum compound, thus, the lack of $\mathrm{pH}$ decrease in C. pacifica may suggest a greater capacity for $\mathrm{pH}$ regulation in this species. Protons released during binding of $\mathrm{HS}^{-}$(from $\mathrm{H}_{2} \mathrm{~S}$ ) may be instantly compensated for by increased proton elimination, resulting in no net change in blood $\mathrm{pH}$ in C. pacifica. This idea is 
supported by measurements indicating that C. pacifica devotes a larger percentage of its gill ATPases (66\%, $\mathrm{n}=2$ ) to the elimination of protons than does C. kilmeri $\left(29 \% \mathrm{H}^{+}\right.$-ATPases, $\mathrm{n}=3$ ), suggesting more efficient $\mathrm{pH}$ regulation in C. pacifica (S.K.G. unpubl. data).

Differences in internal sulfide levels and rates of $\mathrm{H}_{2} \mathrm{~S}$ uptake between Calyptogena kilmeri and C. pacifica almost certainly evolved in association with divergent patterns of sulfide exploitation by these species. The high rate of sulfide consumption in $C$. pacifica ( $11 \mu \mathrm{mol} \mathrm{H}_{2} \mathrm{~S} \mathrm{~g}^{-1}$ clam $^{-1}$, calculated from gill consumption rates), is presumably a consequence of a higher bacterial abundance. This is comparable to sulfide consumption rates measured previously for the fast growing Riftia pachyptila (6 to $17 \mu \mathrm{mol} \mathrm{H}_{2} \mathrm{~S} \mathrm{~g}^{-1}$ animal $\mathrm{h}^{-1}$, calculated from sulfide consumption by trophosome tissue, using an average worm size of $50 \mathrm{~g}$ and $15 \%$ trophosome biomass; Fisher \& Childress 1984). Rates of sulfide uptake may vary for several reasons, including changes in surface area for gas exchange, volume of sulfide-carrying fluid, or the concentration of sulfide-binding component. C. pacifica has a greater foot and blood mass in relation to total soft tissue, as well as an increase in the concentration of zinc. Anomalously high zinc concentrations have been measured in other vesicomyids suggesting, along with our results that zinc concentrations in both C. kilmeri and C. pacifica were correlated positively with blood sulfide levels, that zinc is responsible for the sulfide-binding ability of the component (Roesjadi 1985, Childress et al. 1993). These results suggest that $C$. pacifica is opportunistic and poised for sulfide uptake, even though it may commonly encounter environments with limiting sulfide concentrations. C. pacifica may, therefore, be capable of very rapid rates of sulfide uptake, following periods of sulfide deprivation, but is likely unable to sustain such high rates over long periods.

The increased capacity for sulfide acquisition measured in Calyptogena pacifica appears to result in a greater potential for energy turnover and processing of sulfide by the symbionts. APS reductase has only been found in sulfur bacteria, whereas sulfide oxidase and ATP sulfurylase are also found in a variety of eukaryotic organisms albeit, very high levels of both are typically indicative of the presence of sulfide-oxidizing symbionts (Peck 1974, Powell \& Somero 1985, Fisher 1990). ATP sulfurylase, which is one of the limiting enzymes in substrate level phosphorylation via sulfide oxidation, was not different between the 2 species; thus, it appears that there is no difference in the ability of these symbionts to produce ATP via the last and least efficient step in the conversion of sulfide to energy. Although both C. kilmeri and C. pacifica had sulfide oxidase activities that were comparable to other host species (Powell \& Somero 1985, Brooks et al. 1987,
Fisher et al. 1988), sulfide oxidase activity in C. pacifica was significantly greater than in $C$. kilmeri. This suggests a greater potential for sulfide metabolism related to autotrophic symbiont productivity in C. pacifica. APS reductase activity in C. pacifica was higher than C. kilmeri, and many other bivalves measured previously (Felbeck 1981, Somero et al. 1989). Sulfide oxidase and APS reductase are the enzymes responsible for ATP production from sulfide via oxidative phosphorylation, thus affording a greater capacity for energy production in C. pacifica. Increased bacterial abundance and higher activity of sulfur-metabolizing enzymes suggest an elevated potential for energy generation by the symbionts in C. pacifica.

The presence of intermediate and end products of sulfide oxidation are indicative of the specific chemical pathways and energetic gains available to the symbionts. In addition, intermediate sulfur products may be important for these symbioses by their utility in energy production in the absence of environmental sulfide. Although the oxidation of stored sulfur compounds has been suggested to be of questionable importance for Calyptogena magnifica (Arp et al. 1984), the common appearance in many chemoautotrophic symbioses and lack of significant sulfur levels in aposymbiotic clams suggest an important role in the physiology of these associations. Biochemical measures of elemental sulfur $\left(\mathrm{S}^{\circ}\right)$ have revealed high, but variable, levels in many invertebrate hosts, including vestimentiferan worms (4 to $6 \% \mathrm{~S}^{\circ}$ of trophosome; deBurgh et al. 1989), C. magnifica $\left(1.2 \% \mathrm{~S}^{\circ}\right.$ of gill; Fisher et al. 1988), as well as C. kilmeri $\left(4.7 \% \mathrm{~S}^{\circ}\right)$ and C. pacifica $\left(2.4 \% \mathrm{~S}^{\circ}\right)$ measured in this study. Inter- and intraspecific variation in gill sulfur content may be linked to tolerance to sulfide deprivation, vis-à-vis reliance upon sulfur stores, specific metabolism of symbionts (utilization of $\mathrm{S}^{\circ}$ stores has been shown in clams kept without sulfide), or overall health (many dying clams demonstrate decreased sulfur concentrations). Higher levels of elemental sulfur observed in $C$. kilmeri may result from oxygen conservation in this species. Formation of elemental sulfur utilizes less oxygen than other sulfide oxidation pathways, and may be advantageous for $C$. kilmeri, which is generally exposed to lower environmental $\mathrm{O}_{2}$ levels (Barry et al. 1997). This is supported by preliminary data in which C. kilmeri demonstrated a decrease in $\mathrm{O}_{2}$ consumption relative to sulfide consumption, in whole clam respiration experiments (S.K.G. unpubl. data).

Levels of sulfide oxidation products, other than elemental sulfur, are generally low in most symbioses (Childress et al. 1991). Although the presence of polysulfides is possible, they have not been measured directly in hosts of sulfide-oxidizing symbionts. Polysulfides form via the reaction of $\mathrm{S}^{\circ}$ with excess sulfide, 
but can also arise during prolonged exposure to low $\mathrm{O}_{2}$ levels (Steudel 1989, Fuseler \& Cypionka 1995). We found up to $13 \%$ of the total sulfur content of gills in both Calyptogena kilmeri and C. pacifica consisting of polysulfide compounds. Previous studies have documented high reactivity of elemental sulfur due to abiotic factors, thus, direct interpretation of the composition of samples removed from the host must be viewed with caution (Hageage et al. 1970, Pasteris et al. 2001). Our results, however, are consistent with a model of vesicle structure in which there is a 'core' of microcrystalline elemental sulfur, surrounded, and perhaps stabilized, by an outer zone of organic polysulfides (Steudel 1989).

An interesting question that arises from this research concerns factors controlling productivity in these symbioses. If the productivity of a symbiotic system is influenced primarily by the ability to process sulfide (energy), then the growth rate of the host (a component of host production) might be expected to correlate positively with sulfide uptake and ability of the symbionts to convert sulfide to ATP. This is not the case when we compare Calyptogena pacifica to C. kilmeri. Individual growth rates of C. pacifica, based on mark and recapture studies, are considerably slower than C. kilmeri (3 vs $15 \% \mathrm{yr}^{-1}$, respectively; Barry \& Kochevar 1998). This is surprising given that C. pacifica possesses a seemingly greater potential to process sulfide, as measured by $\mathrm{H}_{2} \mathrm{~S}$ consumption rate, sulfide-binding ability, and internal sulfide levels, as well as a greater potential for energy turnover, as measured by bacterial sulfide oxidation enzymes and bacterial densities. There are 2 alternative hypotheses: (1) the maintenance of adequate carbon flux from the environment to symbiont to host may limit productivity in C. pacifica; or (2) energy expenditure on other pathways, such as $\mathrm{pH}$ regulation or the maintenance of effective sulfide uptake machinery, may limit the energy allocated to growth in C. pacifica. There is evidence to support both hypotheses, and further research on these systems should incorporate all of the above parameters to characterize the breadth of physiological strategies adopted by vesicomyids, as well as other invertebratebacterial symbioses. It is certain, however, that physiological variation among closely-related species exists and includes metabolic potential, growth rate, ion regulation, metabolite uptake, overall carbon movement from environment to symbiont to host, and sulfiderelated functions.

\section{CONCLUSION}

Since the discovery of chemosynthetic symbioses, researchers have focused primarily on single species and even single individuals to gain insight into their physiology. While this has been crucial for advancing the study of these systems, more intrageneric comparative approaches may provide answers to questions still remaining concerning chemoautotrophic symbioses. Broad phylogenetic comparisons of function, form, and habitat, can be complemented by congeneric and even conspecific comparisons that define both the total scope and the subtleties of physiological function. This will ultimately advance our understanding of the mechanisms involved in tightly coupled invertebrate-bacterial symbioses and, specifically in this study, helped to determine the ecological and physiological factors controlling the distribution of vesicomyid bivalves in Monterey Bay. Results concerning the divergent ecological physiology of these clams may be indicative of general processes defining environmental and physiological boundaries for other taxa, as well as the variability of specific solutions to ecophysiological challenges employed by all organisms.

Acknowledgements. Funding for this project was provided by the Monterey Bay Aquarium Research Institute, supported by the Packard Foundation. The authors thank the captain and crew of the RV's 'Pt. Lobos' and 'Western Flyer' and the ROV's 'Ventana' and 'Tiburon'. We also thank Josh Plant (MBARI) and Rob Frank (analytical lab, University of California, Santa Cruz) for logistical help with the FAA technique, Randy Kochevar (Monterey Bay Aquarium) for previous work on Calyptogena kilmeri and C. pacifica as well as his help with the gas chromatograph, and finally, all members of the Barry lab at MBARI.

\section{LITERATURE CITED}

Arp AJ, Childress JJ, Fisher CR Jr (1984) Metabolic and blood gas transport characteristics of the hydrothermal vent bivalve, Calyptogena magnifica. Physiol Zool 57:648-662

Barry JP, Kochevar RE (1998) A tale of two clams: Differing chemosynthetic life styles at cold seep communities in Monterey Bay. Cah Biol Mar 39:329-331

Barry JP, Greene HG, Orange D, Baxter $\mathrm{CH}$ and 5 others (1996) Biologic and geologic characteristics of cold seeps in Monterey Bay, California. Deep-Sea Res Part I 43: 1739-1762

Barry JP, Kochevar RE, Baxter CH (1997) The influence of pore-water chemistry and physiology on the distribution of vesicomyid clams at cold seeps in Monterey Bay: Implications for patterns of chemosynthetic community organization. Limnol Oceanogr 42:318-328

Bartlett JK, Skoog DA (1954) Colorimetric determination of elemental sulfur in hydrocarbons. Anal Chem 26: 1008-1011

Brooks JM, Kennicutt MC II, Fisher CR, Macko SA, Cole K, Childress JJ, Bidigare RR, Vetter RD (1987) Deep-sea hydrocarbon seep communities: Evidence for energy and nutritional carbon sources. Science 238:1138-1142

Cavanaugh CM (1983) Symbiotic chemoautotrophic bacteria in marine invertebrates from sulphide-rich habitats. Nature 302:58-61

Childress JJ, Fisher CR (1992) The biology of hydrothermal 
vent animals: physiology, biochemistry, and autotrophic symbioses. Oceanogr Mar Biol Annu Rev 30:337-441

Childress JJ, Arp AJ, Fisher CR Jr (1984) Metabolic and blood characteristics of the hydrothermal vent tube worm Riftia pachyptila. Mar Biol 83:109-124

Childress JJ, Fisher CR, Favuzzi JA, Sanders NK (1991) Sulfide and carbon dioxide uptake by the hydrothermal vent clam, Calyptogena magnifica and its chemoautotrophic symbionts. Physiol Zool 64:1444-1470

Childress JJ, Fisher CR, Favuzzi JA, Arp AJ, Oros DR (1993) The role of a zinc-based, serum-borne sulphide-binding component in the uptake and transport of dissolved sulphide by the chemoautotrophic symbiont containing clam Calyptogena elongata. J Exp Biol 179:131-158

Corliss JB, Dymond J, Gordon LI, Edmond JM and 7 others (1979) Submarine thermal springs on the Galapagos Rift. Science 203:1073-1083

de Burgh ME, Juniper SK, Singla CL (1989) Bacterial symbiosis in northeast Pacific vestimentifera: A TEM survey. Mar Biol 101:97-105

Distel DL (1998) Evolution of chemoautotrophic endosymbioses in bivalves. Bioscience 48:277-286

Embley RW, Eittreim SL, McHugh CM and 7 others (1990) Geological setting of chemosynthetic communities in the Monterey Fan Valley system. Deep-Sea Res Part I 37:1651-1667

Felbeck H (1981) Chemoautotrophic potential of the hydrothermal vent tube worm, Riftia pachyptila Jones (Vestimentifera). Science 213:336-338

Fiala-Médioni A, Métivier C (1986) Ultrastructure of the gill of the hydrothermal vent bivalve Calyptogena magnifica, with a discussion of its nutrition. Mar Biol 90:215-222

Fisher CR (1990) Chemoautotrophic and methanotrophic symbioses in marine invertebrates. Rev Aquat Sci 2:399-436

Fisher CR Jr, Childress JJ (1984) Substrate oxidation by trophosome tissue from Riftia pachyptila Jones (Phylum Pogonophora). Mar Biol Lett 5:171-184

Fisher CR, Childress JJ, Arp AJ, Brooks JM and 13 others (1988) Variation in the hydrothermal vent clam, Calyptogena magnifica, at the Rose Garden vent on the Galapagos spreading center. Deep-Sea Res 35:1811-1832

Fuseler K, Cypionka H (1995) Elemental sulfur as an intermediate of sulfide oxidation with oxygen by Desulfobulbus propionicus. Arch Microbiol 164:104-109

Girard JE, Glatz JA (1981) Ion chromatography with conventional HPLC instrumentation. Am Lab 10:26-35

Goffredi SK, Childress JJ, Desaulniers NT, Lallier FH (1997) Sulfide acquisition by the vent worm Riftia pachyptila appears to be via uptake of $\mathrm{HS}^{-}$, rather than $\mathrm{H}_{2} \mathrm{~S}$. J Exp Biol 200:2609-2616

Hageage GJ, Eanes ED, Gherna RI (1970) X-ray diffraction studies of the sulfur globules accumulated by Chromatium species. J Bacteriol 101:464-469

Hagen KD, Nelson DC (1997) Use of reduced sulfur compounds by Beggiatoa spp.: Enzymology and physiology of marine and freshwater strains in homogeneous and gradient cultures. Appl Environ Microbiol 63:3957-3964

Kelly DP (1989) Physiology and biochemistry of unicellular sulfur bacteria. In: Schlegel HG, Bowien B (eds) Autotrophic bacteria. Science Tech Publishers, Wisconsin, p 193-218

Lauren DR, Watkinson JH (1985) Elemental sulfur analysis using high-performance liquid chromatography on 10-mm rigid polymer particles. J Chromatogr 348:317-320

Lowry OH, Rosebrough NJ, Farr L, Randall RJ (1951) Protein measurement with the Folin Phenol Reagent. J Biol Chem 193:267-275

Naehr TH, Stakes DS, Moore WS (2000) Mass wasting, ephemeral fluid flow, and barite deposition on the California continental margin. Geology 28:315-318

Nelson DC, Hagen KD (1995) Physiology and biochemistry of symbiotic and free-living chemoautotrophic sulfur bacteria. Am Zoolt 35:91-101

Orange DL, Greene HG, Reed D, Martin JB, McHugh CM, Ryan WBF, Maher N, Stakes D, Barry J (1999) Widespread fluid expulsion on a translational continental margin: Mud volcanoes, fault zones, headless canyons, and organic-rich substrate in Monterey Bay, California. GSA Bulletin 111: 992-1009

Pasteris J, Freeman J, Goffredi S, Buck K (2001) Raman spectroscopic and laser scanning confocal microscopic analysis of sulfur in living sulfur-precipitating marine bacteria. Chem Geol 180:3-18

Peck HD, Deacon TE, Davidson JT (1965) Studies on Adenosine 5'-Phosphosulfate Reductase from Desulfovibrio desulfuricans and Thiobacillus thioparus. Biochim Biophys Acta 96:429-441

Peck HD Jr (1974) Sulfation linked to ATP cleavage. In: Boyer P (ed) The enzymes, Vol X. Academic Press, New York, p 651-669

Pörtner HO, Boutilier RG, Tang Y, Toews DP (1990) Determination of intracellular $\mathrm{pH}$ and $\mathrm{PCO} 2$ after metabolic inhibition by fluoride and nitrilotriacetic acid. Respir Physiol 81:255-274

Powell MA, Somero GN (1985) Sulfide oxidation occurs in the animal tissue of the gutless clam, Solemya reidi. Biol Bull 169:164-181

Powell MA, Somero GN (1986) Adaptations to sulfide by hydrothermal vent animals: sites and mechanisms of detoxification and metabolism. Biol Bull 171:274-290

Renosto F, Martin RL, Borrell JL, Nelson DC, Segel IH (1991) ATP sulfurylase from trophosome tissue of Riftia pachyptila (hydrothermal vent tube worm). Arch Biochem Biophys 290:66-78

Roesjadi G, Young JS, Crecelius EA, Thomas LE (1985) Distribution of trace metals in the hydrothermal vent clam, Calyptogena magnifica. Bull Biol Soc Wash 6:311-324

Sanders NK, Childress JJ (1991) The use of single column ion chromatography to measure the concentrations of the major ions in invertebrate body fluids. Comp Biochem Physiol 98A:97-100

Santavy DL, Willenz P, Colwell RR (1990) Phenotypic study of bacteria associated with the caribbean sclerosponge, Ceratoporella nicholsoni. Appl Environ Microbiol 56: 1750-1762

Schedel J, Truper H (1980) Anaerobic oxidation of thiosulfate and elemental sulfur in Thiobacillus denitrificans. Arch Microbiol 124:205-210

Shively JM, Bryant DA, Fuller RC, Konopka AE, Stevens SE, Strohl WR (1988) Functional inclusions in prokaryotic cells. International Journal of Cytology 113:35-87

Somero GN, Childress JJ, Anderson AE (1989) Transport, metabolism and detoxification of hydrogen sulfide in animals from sulfide rich marine environments. Crit Rev Aquat Sci 1:591-614

Steudel R (1989) On the nature of elemental sulfur $\left(\mathrm{S}^{\circ}\right)$ produced by sulfur-oxidizing bacteria: A model for $\mathrm{S}^{\circ}$ globules. In: Schlegel HG, Bowien B (eds) Autotrophic bacteria. Science Tech Publishers, Wisconsin, p 289-302.

Vetter RD (1985) Elemental sulfur in the gills of three species of clams containing chemoautotrophic symbiotic bacteria: a possible inorganic energy storage compound. Mar Biol 88:33-42

Vismann B (1991) Sulfide tolerance: Physiological mechanisms and ecological implications. Ophelia 34:1-27 